\title{
Pharmacological activity and mechanism of action of plants with anti- inflammatory properties found in brazilian flora
}

\author{
Atividade farmacológica e mecanismo de ação de plantas com propriedades anti- \\ inflamatórias encontradas na flora brasileira \\ Actividad farmacológica y mecanismo de acción de plantas con propiedades \\ antiinflamatorias encontradas en flora brasileña
}

\begin{abstract}
Kessya Lanny Sousa Dantas ${ }^{1 *}$, Kassyo Lenno Sousa Dantas ${ }^{1}$, Eduardo Soares dos Santos ${ }^{1}$, Júlio Evangelista de Lucena', Milena Sousa Freitas ${ }^{1}$, Francisco Monteiro da Silva Júnior ${ }^{2}$, Adriano Stênio Genaro$^{2}$, Cristiane Santos Silva e Silva Figueiredo', Domingos Magno Santos Pereira'.
\end{abstract}

\begin{abstract}
Objective: To describe the importance of medicinal plants in the social and pharmacological context, demonstrating the anti-inflammatory therapeutic potential and the mechanism of action of drugs present in the chemical composition of four plants present in the Brazilian flora. Methods: A bibliographic survey on the topic was carried out, using the descriptors: Activity, Anti-inflammatory, Plants, Flora, Brazilian. In Scielo, Google Scholar and PUBMED databases. For the inclusion of works, the following criteria were used: Articles from research relevant to the topic (regardless of date) and relevant publications from the year 2007. Results: The inflammatory process is a target for the treatment of various diseases and development new treatments are needed. We discuss here the anti-inflammatory potential and the mechanism of action of the following plants: Uncaria tomentosa, Schinus terebinthifolius Raddi and Mentha piperita demonstrated through in vitro studies and murine models of diseases. The species showed antiinflammatory action by reducing the production of inflammatory mediators and inhibiting the activity of important proinflammatory enzymes, such as phospholipase A2 and cycloxygenase. Final considerations: The four plant species covered in this article had significant anti-inflammatory effects, therefore, they can be suggested as a source of potential new drugs.
\end{abstract}

Keywords: Activity, Anti-inflammatory, Plants, Flora, Brazilian.

\section{RESUMO}

Objetivo: Descrever a importância de plantas medicinais no contexto social e farmacológico, demonstrando o potencial terapêutico anti-inflamatório e o mecanismo de ação das drogas presentes na composição química de quatro plantas presentes na flora brasileira. Métodos: Realizado um levantamento bibliográfico sobre o tema, utilizando os descritores: Atividade, Anti-inflamatória, Plantas, Flora, Brasileira. Nas bases de dados Scielo, Google Scholar e PUBMED. Para a inclusão dos trabalhos utilizou-se os seguintes critérios: Artigos oriundos de pesquisas pertinentes ao tema (independente da data) e publicações relevantes a partir do ano de 2007. Resultados: O processo inflamatório é alvo para o tratamento de diversas doenças e o desenvolvimento de novos tratamentos são necessários. Discutimos aqui sobre o potencial anti-inflamatório e o mecanismo de ação das seguintes plantas: Uncaria tomentosa, Schinus terebinthifolius Raddie Mentha piperita demonstrados através de estudos in vitro e modelos murinos de doenças. As espécies apresentaram ação anti-inflamatória através da redução na produção de mediadores inflamatórios e inibição da atividade de importantes enzimas pró-inflamatórias, tais como a fosfolipase A2 e as cicloxigenase. Considerações finais: As quatro espécies de plantas abordadas neste artigo apresentaram efeitos anti-inflamatórios significativos, portanto, podem ser sugeridas como fonte de potenciais novos fármacos.

Palavras-Chave: Atividade, Anti-inflamatória, Plantas, Flora, Brasileira.

${ }^{1}$ Universidade CEUMA (UNICEUMA), Imperatriz - MA. *E-mail: kessyadantasbiomed@gmail.com

${ }^{2}$ Universidade Federal do Maranhão (UFMA), Imperatriz - MA. 


\section{RESUMEN}

Objetivo: Describir la importancia de las plantas medicinales en el contexto social y farmacológico, demostrando el potencial terapéutico antiinflamatorio y el mecanismo de acción de los fármacos presentes en la composición química de cuatro plantas presentes en la flora brasileña. Métodos: Se realizó un relevamiento bibliográfico sobre el tema, utilizando los descriptores: Actividad, Antiinflamatorio, Plantas, Flora, Brasileño. En bases de datos Scielo, Google Scholar y PUBMED. Para la inclusión de trabajos se utilizaron los siguientes criterios: Artículos de investigaciones relevantes al tema (independientemente de la fecha) y publicaciones relevantes del año 2007. Resultados: El proceso inflamatorio es un objetivo para el tratamiento de diversas enfermedades y el desarrollo. se necesitan nuevos tratamientos. Aquí discutimos el potencial antiinflamatorio y el mecanismo de acción de las siguientes plantas: Uncaria tomentosa, Schinus terebinthifolius Raddi y Mentha piperita demostrado a través de estudios in vitro y modelos murinos de enfermedades. La especie mostró acción antiinflamatoria al reducir la producción de mediadores inflamatorios e inhibir la actividad de importantes enzimas proinflamatorias, como la fosfolipasa A2 y la cicloxigenasa. Consideraciones finales: Las cuatro especies de plantas cubiertas en este artículo tuvieron efectos antiinflamatorios significativos, por lo tanto, pueden sugerirse como una fuente de posibles nuevos medicamentos.

Palabras clave: Actividad, Antiinflamatoria, Plantas, Flora, Brasileña.

\section{INTRODUCTION}

The inflammatory response is a dynamic and physiological mechanism where the body defends itself against harmful stimuli, such as infections, for example. The inflammatory phenomenon occurs after recognition of the initial stimulus (usually chemical, physical or biological), such as a cut or a skin infection by cells of the immune system, inducing them to produce inflammation mediators, such as vasoactive substances, cytokines and chemokines (KASSUYA CAL, 2013).

The local production of inflammatory mediators induces the outflow of fluids, cells and proteins from the bloodstream to the inflammation site, making evident the five well-known cardinal signs of inflammation which are: The increase in temperature (heat), redness, swelling, pain and consequent temporary loss of function of the affected tissue/organ. Several harmful stimuli can activate the cells of the immune system and start an inflammatory process, such as the presence of pathogens, cuts, bruises, toxic compounds, radiation, cell death, among others. Such stimuli are recognized by leukocytes through receptors present in these cells, inducing the reactivity of the immune system and generating inflammation in order to eliminate the causative agent for later induction of an anti-inflammatory response and activation of the healing pathways (CHEN L, et al., 2018).

The inflammation process is target for the treatment of several diseases and the development of new treatments are required, once most of the allopathic medicines available are produced industrially with isolated substances (drugs) from the biodiversity, of which, more than $50 \%$ are from vegetable raw material origin. On the other hand, these drugs are responsible for a large amount of harmful reactions, therefore, must be administered under medical prescription and pharmacovigilance (WONGRAKPANICH S, et al., 2018).

In view of the need to develop new treatments for inflammation, which can be a symptom of several pathologies, the use of medicinal plants has been gaining space in the scientific community as an alternative therapy to conventional disease treatments (FONSECA FIC, 2019). The incredible biodiversity of the Brazilian flora, which currently comprises at about 55.000 catalogued plant species, has the greatest plant genetic diversity in the world (mainly in the region called Legal Amazon), in which at about only $8 \%$ of these species were studied and had some of their therapeutic actions characterized and proven (FONSECA FIC, 2019; SOUSA IJO, 2017).

The treatment of diseases with medicinal plants is an effective and economically accessible alternative, since culturally most of the people cultivate some type of plant that can be used for the production of different forms of use. The effectiveness of medicinal plants has been and continues to be proven throughout human evolution, mainly through the emergence of biotechnological and chemical techniques, which allowed a better characterization of the chemical components of the plant raw material; and the development of disease models studied in vivo and in vitro (MONTEIRO DCS and BRANDELLI CLC, 2017). 
Thus, the present study aimed to describe the importance of the medicinal plants in a social and pharmacological context, demonstrating the anti-inflammatory therapeutic potential and the mechanism of action of drugs present in the chemical composition of three plants found in Brazilian flora.

\section{METHODS}

The present work is a literature review. A bibliographic survey of 50 relevant original publications on the topic was carried out, using the descriptors: Inflammation, action, anti-inflammatory, plants, mechanism of action. The works were searched in the Scielo, Google Scholar and PUBMED databases. For the inclusion of works, the following criteria were used: Research articles relevant to the theme (regardless of date) and relevant posts from 2007 until now. For exclusion, the absence of in vitro and in vivo research in the works was observed, totaling 39 publications used for drafting the text.

\section{RESULTS}

\section{Pharmacology of inflammation}

The initial mechanisms of the inflammatory response depend on the different types of stimuli and the site where the process will occur, however, in general terms, they share similarities, such as: (I) recognition of molecular patterns associated with pathogens (PAMP) and cellular damage (DAMP) by receptors of the immune cells (leukocytes); (II) activation of immune system cells; (III) production/release of pro-inflammatory cytokines and chemokines; (IV) activation of the vascular endothelium and recruitment of leukocytes; (V) production of reactive oxygen (ROS) and nitrogen (NRS) species (CHEN L, et al., 2018). The summary of the leukocyte activation and the production of cytokines and chemokines can be seen in Figure 1.

Figure 1 - After cells of the immune system (leukocytes) are activated by pattern recognition receptors (PRR), they induce their genes to express proteins related to inflammatory processes such as chemokines, which work by promoting the chemotaxis of more immune cells ; and cytokines, which act by activating these leukocytes with subsequent activation of oxidative pathways with the intuition to fight the pathogen / other stimulus.

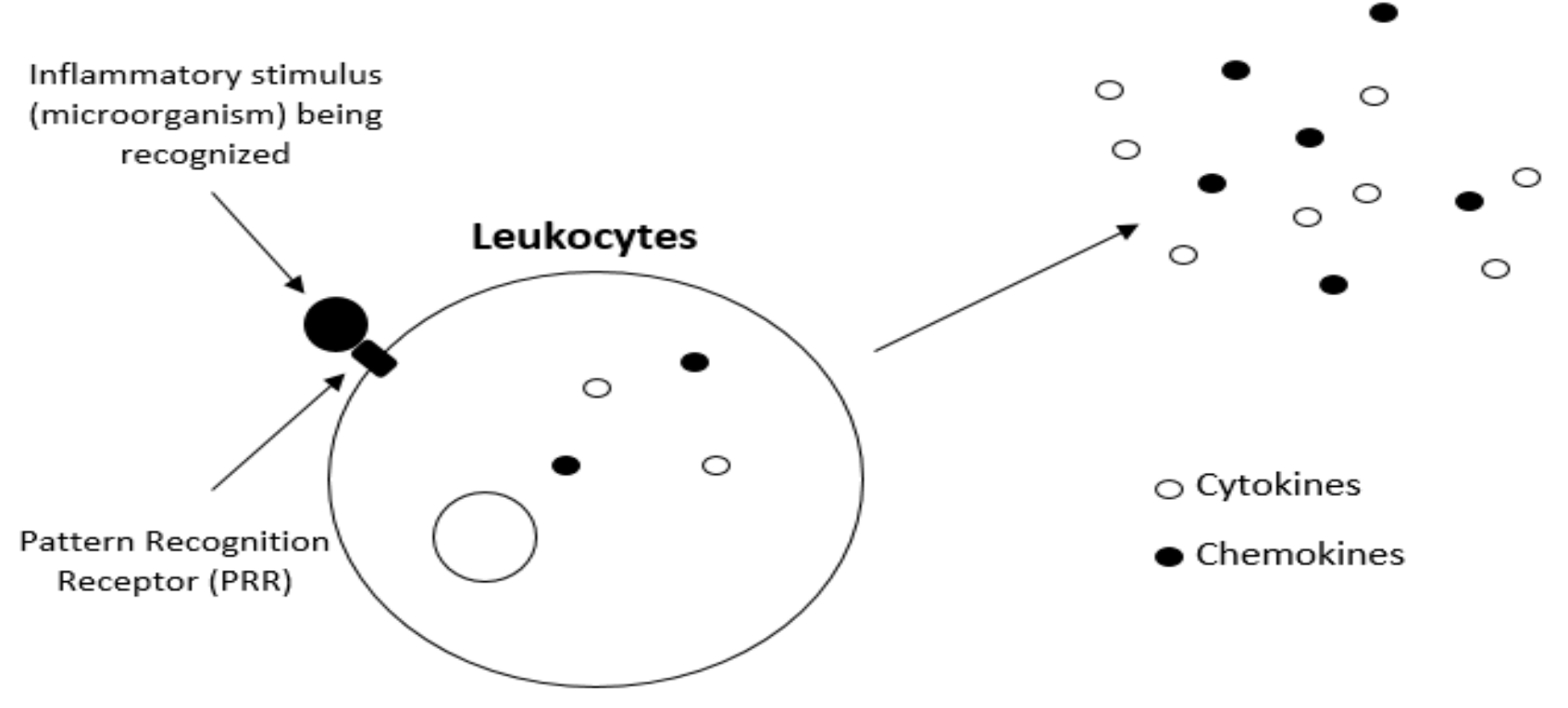

Source: Dantas KLS, et al., 2020.

The production of oxidizing substances such as ROS and RNS are required for killing pathogens, once these molecules act attacking proteins and lipids of the cell membranes of both pathogen and host cells. Among the main ROS produced during inflammation we can mention the superoxide anion (O-) and the hydrogen peroxide (H2O2); On the other hand, among the main RNS, we can detach nitric oxide (NOx). It is also important to note that ROS and RNS react with each other to form more powerful free radicals, such as peronitrite (ONOO-) (CHEN L, et al., 2018). 
The excessive production of ROS and RNS is called oxidative/nitrosative stresses in which is controlled by antioxidant system of the body, such as catalase and glutathione system. The release of pro inflammatory cytokine was already demonstrated to be linked with the enhanced oxidative/nitrosative stresses, therefore, contributing to the parasites and host cell's death (LIGUORI I, et al., 2018). Antioxidant drugs are that ones that can reduce the production of these molecules. The aggression caused by ROS/RNS trigger a tissue response against the etiologic agent of inflammation, activating the cascade of arachidonic acid and subsequent production of new inflammatory mediators derived from the cells of the original tissue (TALLIMA $H$ and EL RIDI R, 2018).

In the tissue, the enzyme phospholipase A2 acts on membrane phospholipids, releasing arachidonic acid; this, in turn, may suffer the action of two types of enzymes, cycloxygenases (COX, three isoforms) and lipoxygenase (LOX). COX enzymes bind to arachidonic acid and produce prostaglandins (causes pain, fever, vasodilation, etc.), thromboxanes (activation of platelet aggregation, vasodilation, etc.) and prostacyclins (platelet inhibition, vasodilation, etc.), which are molecules responsible for large parts of the symptoms (TALLIMA H and EL RIDI R, 2018). On the other hand, when arachidonic acid binds to LOX, the products generated are mainly leukotrienes (causes leukocyte recruitment, among other diverse functions) and lipoxins (inhibition of leukocyte recruitment, etc.). A dynamic mechanism between the products generated between COX and LOX keeps the inflammatory process constant and under certain control, such as the formation of thrombi and clots (to stop bleeding) and the control of leukocyte infiltration (activation and inhibition of chemotaxis) (TALLIMA H and EL RIDI R, 2018).

With regard to the effects of anti-inflammatory drugs in the body, it is important to note that COX enzyme has three isoforms: COX1 (Physiological), COX2 (inflammatory) and COX3 (role still unclear). The inflammatory process is directly linked to the COX2 isoform, which acts by producing several mediators, such that motioned above. On the other hand, COX1 is called physiological, as it acts to induce the production of mucus for gastric protection against hydrochloric acid $(\mathrm{HCL})$, in addition to regulating renal function (MITCHELL JA and KIRKBY NS, 2019). Nowadays, several allopathic anti-inflammatory drugs are available on the market, the main ones belonging to two classes of drugs: Steroidal and non-steroidal drugs; which act by inhibiting enzymes important for the production of inflammatory mediators, such as the enzymes responsible for the arachidonic acid cascade. In general, the mechanism of action of these drugs is based mainly on the inhibition of phospholipase A2 (steroidal drugs) and COX (non-steroidal) enzymes, as shown in Figure 2 (FREITAS PR, et al., 2019).

Figure 2 - Cascade of the arachidonic acid. Phospholipase A2 acts on phospholipids in cell membranes that are in the inflammatory process, producing arachidonic acid. This, in turn, suffers the action of two other enzymes, LOX, which transforms arachidonic acid into leukotrienes (promoting bronchospasm, increasing vascular permeability and leukocyte chemotaxis) and lipoxins (inhibiting neutrophil adhesion and chemotaxis); and COX enzymes, which transform arachidonic acid into prostaglandins (vasodilation, increased vascular permeability), prostacyclins (vasodilation and inhibition of platelet aggregation) and thromboxanes (vasoconstriction and promote platelet aggregation).
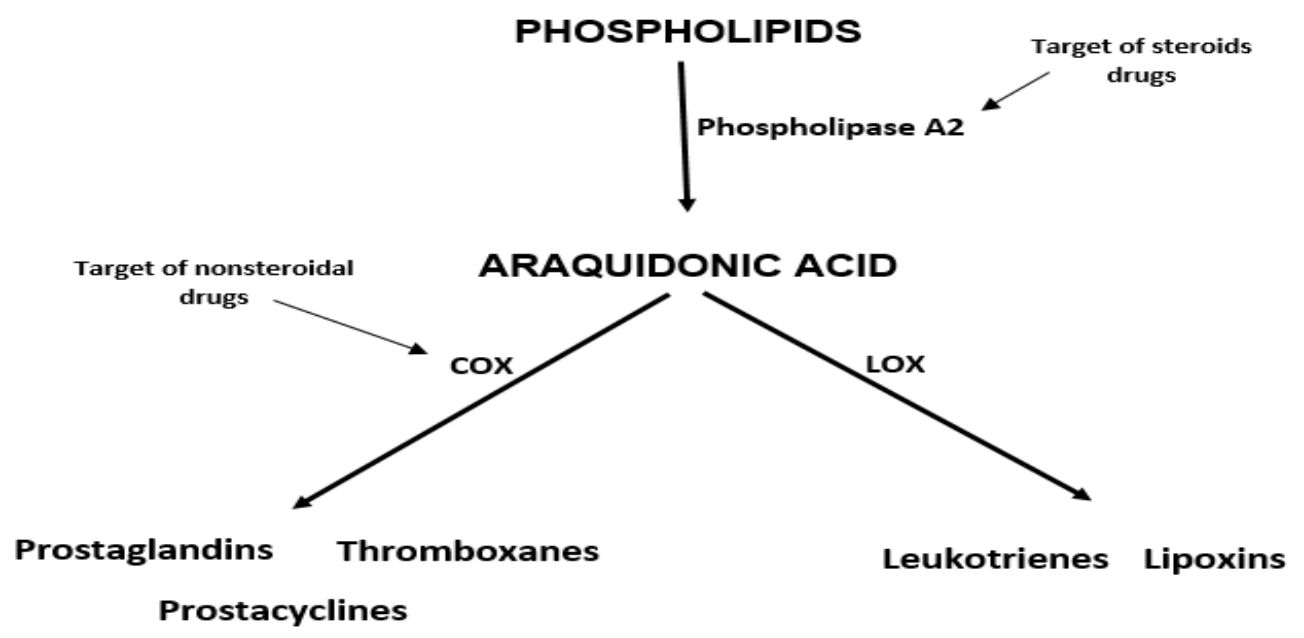

Source: Dantas KLS, et al., 2020. 
In this case, non-selective drugs act as COX enzyme inhibitors, acting on both the inflammatory (COX2) and physiological (COX1) isoforms, causing deleterious effects in the body, such as renal dysfunction and gastrointestinal bleeding and contributing for the development of gastritis and ulcers (BALBINO CA, 2011). COX2 selective inhibitory drugs have also been developed in order to reduce adverse reactions, however, the non-selective COX2 blockade has been shown to be directly linked to the appearance of thrombi and circulation problems (BALBINO CA, 2011).

Regarding steroidal or glucocortincoidanti-inflammatory drugs, they are widely prescribed for their immunosuppressive and anti-inflammatory effects in the treatment of various diseases, mainly rheumatic ones, however, their use becomes limited by the amount of adverse reactions caused, such as suppression acute inflammation, immunosuppression, depression of thyroid function, reduction of sex hormone synthesis, muscle cell atrophy, sodium retention (causing fluid retention and swelling), among others. The mechanism of action of these drugs is linked to the blocking of the functions of the phospholipase A2, preventing the production of arachidonic acid, therefore, inhibiting both the COX and LOX pathways (ANTI SMA, et al., 2008).

Speaking more broadly, drugs with anti-inflammatory activity can have several targets in the body, such as those produced by leukocytes, such as cytokines, chemokines and reactive oxygen (ROS) and nitrogen (RNS) species; and those produced in response to tissue aggression, such as the mediators produced by the arachidonic acid cascade mainly due to action of the enzymes phospholipase A2 and COX2. In next session, we will discuss about the anti-inflammatory action of three species of plants easily found in Brazilian flora, as well as their mechanism of action in several inflammatory disease models.

\section{DISCUSSION}

\section{Plant 1 - Cat's claw plant - uncaria tomentosa}

Uncaria tomentosa (UT), also known as cat's claw (among other names depending on the region it is found), belongs to the Rubiaceae family, originally from the Brazilian and Peruvian Amazon. It is characterized as a climbing shrub that rests on other trees in search of sunlight, reaching up to $20 \mathrm{~m}$ in length. It is widely used in traditional medicine for its anti-inflammatory, antioxidant and antimicrobial properties (HONÓRIO ICG, et al., 2017).

Phytochemical studies indicate a diversity of constituents in its composition, the main classes of compounds identified in UT include oxindole and indole alkaloids, pyroquinovic acid glycosides, proanthocyanidins, organic acids, sterols and polyoxygenated riterpenes, which are suggested as responsible for the therapeutic effects of the plant, demonstrated mainly in animal models and cell culture (KAISER S, et al., 2020).

Azevedo BC (2019) and collaborators evaluated the antioxidant potential of the aqueous extract of UT leaves and their main alkaloids, mitrafilina and isomitrafilina, in vitro, using standard tests of reduction of the 2,2-diphenyl-1-picrilhidrazil (DPPH), capture of 2,2'-azinobis (3-ethylbenzothiazoline-6-sulfonic acid) (ABTS) and reduction of the iron ion $\left(\mathrm{Fe}^{3+}\right.$ to $\left.\mathrm{Fe}^{2+}\right)$ (FRAP).

The extract showed moderate antioxidant activity when compared to ascorbic acid (positive control) in all methods. In another study, the anti-inflammatory activity of the aqueous bark and leaf extracts were evaluated in macrophage cultures (RAW264.7-Luc) stimulated with lipopolysaccharide (LPS). The results demonstrated that both extracts reduced the expression of the nuclear factor kappa- $B$, decreasing the production of cytokines, such as interleukin-6 (IL-6) and tumor necrosis factor-alpha (TNF- $\alpha$ ) (AZEVEDO BC, et al., 2018). In the same study, the reduction of hyperresponsiveness and inflammation were evaluated in vivo in an asthma model induced by ovalbumin in BALB/c mice. The treatment with the same extracts mentioned above reduced the bronchial hyperresponsiveness and lung inflammation. Still, both the aqueous extract of the leaf and bark reduced the number of eosinophils in the bronchial-alveolar lavage (BAL), in addition to decreasing the levels of the cytokines interleukin-4 (IL-4) and interleukin-5 (IL-5) in samples of the lung tissue (AZEVEDO BC, et al., 2018).

Rojas-Duran R, et al. (2012) studied the anti-inflammatory activity of the chloroform extract (rich in mitophylline) from UT shells in rats treated orally and stimulated intraperitoneally by LPS (model of systemic inflammation). 
The extract inhibited at about $50 \%$ of the production/release of cytokines, mainly IL-1 $1 \alpha, I L-1 B, I L-17$ and TNF-a. Aguilar JL, et al. (2002) using a carrageenan-induced paw edema model in BALB/c mice, demonstrated that the aqueous and ethanolic extracts of UT have anti-inflammatory effects by decreasing the synthesis of prostaglandins (and other related molecules), an effect similar to the control animals treated with indomethacin (non-steroidal anti-inflammatory).

In another study by Cisneros FJ, et al. (2005), they investigated the effect of an aqueous decoction of the UT shells on a model of acute pneumonitis in vivo induced by inhalation of ozone in mice. In the bronchoalveolar lavage, a significant reduction was observed in the levels of proteins and in the population of polymorphonuclear cells (mainly neutrophils), in addition to a lower degree of epithelial necrosis (result linked to the antioxidant effect of the plant). Therefore, based on the information published above about Uncaria tomentosa, we can suggest it as a plant with proven anti-inflammatory therapeutic potential, presenting itself as a candidate for alternative therapies and the development of new drugs with the potential to act on several kind of inflammatory diseases.

\section{Plant 2 - Red aroeira - schinus terebinthifolius raddi}

Schinus terebinthifolius Raddi (STR), also called brazilian peppertree is a native specie from the South America that belongs to the family Anacardiaceae. It is characterized as a medium sized and dioecious tree, with aromatic leaves. In popular medicine it is often used to treat infectious and inflammatory diseases, among others (ROSAS EC, et al., 2019). Phytochemical studies indicate a wide variety of constituents in its composition, among them, riterpenes, phenolic lipids, biflavonoids, phenols, cinnamic acid derivatives, flavones, xanthones, flavonoids, free steroids, saponins, tannins, ethyl gallate, myricethrin and quercitrin (DE OLIVEIRA VS, et al., 2020).

Rosas EC, et al. (2019) conducted studies with the SRT hydroalcoholic extract to evaluate the antiinflammatory activity in an experimental model of zymosan-induced arthritis in male swiss mice. It was found that the extract showed anti-inflammatory activity linked to local reduction/inhibition of the chemokine CXCL$1 / \mathrm{KC}$, and of the cytokines IL-1 $\alpha$, TNF- $\alpha$ and IL-6. Da Rocha PS, et al. (2018) evaluated the antioxidant activity of the SRT using the DPPH free radical scavenging method, evaluation of the activity of antioxidant enzymes (catalase enzyme, superoxide dismutase and glutathione) in cell culture and hemolysis and lipid peroxidation in erythrocytes.

The study showed significant antioxidant activity by eliminating free radicals and inhibiting hemolysis and lipid peroxidation in human erythrocytes incubated with doxorubicin; in addition, the plant extract was also able to increase the activity of the antioxidant enzymes, such as catalase and superoxide dismutase. It is important to note that, antioxidant drugs are related with diminished tissue damage.

Still, De Oliveira VS, et al. (2020) worked with methanolic and ethanolic extracts from STR fruits to evaluate the plant's antioxidant capacity in culture media containing yeasts (Saccharomyces cerevisiae) exposed to hydrogen peroxide $\left(\mathrm{H}_{2} \mathrm{O}_{2}\right)$, besides carrying out reduction tests with DPPH radicals and oxygen radical absorption capacity (ORAC). The extract was able to reduce the damage caused by oxidative stress promoted by $\mathrm{H}_{2} \mathrm{O}_{2}$ in $\mathrm{S}$. cerevisiae cells and exhibited a significant antioxidant capacity in the DPPH and ORAC methods.

Jaim MK, et al. (1995) in the study "Specific competitive inhibitor of secreted phospholipase A2 from berries of Schinus terebinthifolius", demonstrated that the chemical compounds 3-amasticadienoico (schinol) and masticadienoico acid, isolated from the crude extract of ethyl acetate from SRT act as specific inhibitors for phospholipase A2, blocking the cascade of the arachidonic acid and consequently the production of inflammatory mediators derived from COX and LOX enzymes, therefore, presenting an effect similar to steroidal anti-inflammatory drugs.

Another study aimed to investigate the effect of the SRT extract on the formation of histamine-induced paw edema in rats. The results demonstrated that this plant has antihistamine effects, reducing the formation of edema and tissue concentrations of histamine. Thus, in addition to having anti-inflammatory effect, SRT is also suggested as an antiallergic (NUNES-NETO PA, et al., 2017). 
The literature that reports the anti-inflammatory activity of SRT is extensive and varies in several experimental models of inflammatory diseases. In addition, phytopharmaceuticals produced with this plant input already exist on the market, however, studies focusing on the isolation of active ingredients are still required for a better biochemical understanding of the anti-inflammatory mechanisms of this plant.

\section{Plant 3 - Hortelã - mentha piperita}

Mentha piperita (MP) also called mint is a hybrid plant obtained by crossing Mentha aquatica and Mentha spicata, belonging to the Lamiaceae family. It is a perennial herb native from the European Mediterranean that is currently grown in many parts of the world, including the Brazilian territory. It is widely used in traditional medicine for its anti-inflammatory, antioxidant, antimicrobial and expectorant properties (HERRO E, et al., 2010).

Phytochemical studies indicate a diversity of constituents in its composition, they are, mainly, monoterpenes, menthol, menthol, mentin acetate, neomentol acetate, neomentol, isomentol, atheripene, pipertitinone oxide, isomentone, limonene, $\alpha$-pinene, $\beta$ - pinene and sesquiterpenes (MELO WF, et al., 2018).

Several recent studies that have assessed the pharmacological potentials of the MP highlight its potent anti-inflammatory and antioxidant activities attributed to the inhibitory action of the most varied chemical constituents of this plant on the free radicals of 2,2-diphenyl-1-picrilhidrazil (DPPH) and its reducing power for Nitric Oxide (NO) and prostaglandins (PG), important signaling molecules present in inflammatory reactions, as discussed below (SINGH R, et al., 2015).

Sun Z, et al. (2014) carried out studies with the essential oil of the MP to evaluate the anti-inflammatory and antioxidant activity in an inflammation model with RAW 264.7 cells (macrophages) stimulated by LPS. It was observed that the oil of this plant is able to inhibit the production of nitric oxide (NO) and prostaglandins E2 in cell culture. In the same study in a model of ear edema induced by croton oil in mice, compared to the non-steroidal anti-inflammatory drug indomethacin, MP exhibited significantly high anti-inflammatory activity, reducing the edematous response. These results can be explained by the presence of sesquiterpenes, such as espathulenol, cadinene, karyophyllene and karyophyllene oxide in the oil, that are compounds with antiinflammatory effect.

Li YX, et al. (2017) worked investigating the antiviral, anti-inflammatory and antioxidant activities of the ethanolic extract of MP leaves. The antioxidant activity was determined by the reduction of DPPH radicals, the hydroxyl radical elimination test and the superoxide anion reduction assay. Respectively, it showed a significant reduction of DPPH radicals, elimination of hydroxyl radicals and reduction of superoxide anions, therefore, the extract of this plant was considered by the authors as a promising antioxidant agent.

In cell cultures, the anti-inflammatory activity of the MP was evaluated using a line of murine macrophages RAW 264.7 activated with LPS, and to measure the anti-inflammatory potential, the production of NO, TNF-a, IL-6 and Prostaglandin E2 (PGE2) was determined. The ethanolic extract was able to significantly decrease the production of all the assessed inflammatory mediators in the culture medium (LI YX, et al., 2017).

Kehili S, et al. (2020) studied the anti-inflammatory activity of the MP essential oil in models of ear edema (induced by carrageenan) and skin wounds in mice. The results showed that the essential oil was able to reduce both the formation of edema and skin inflammation. In addition, it also reduced nociceptivity (pain) at all doses tested in the study. Based on the information reported here and on the vast published literature on mint in in vivo and in vitro models of inflammation, we suggest it as an important source of active compounds with anti-inflammatory and antioxidant activity. 
Frame 1 - Summary of plant species, laboratory model, anti-inflammatory mechanisms and references used in this work. A plant can exhibit anti-inflammatory activity through the modulation of different inflammation pathways and antioxidant activities of some compounds.

\begin{tabular}{|c|c|c|c|}
\hline SPECIES & MODEL USED & ANTI-INFLAMMATORY MECHANISM & REFERENCES \\
\hline $\begin{array}{c}\text { Uncaria } \\
\text { tomentosa }\end{array}$ & $\begin{array}{l}\text { [1] In vitro; } \\
\text { [2] Macrophages culture; } \\
\text { [3] Ovalbumin-induced asthma in BALB/c } \\
\text { mice; } \\
\text { [4] Systemic inflammation in rats stimulated } \\
\text { by LPS (intraperitoneal route); } \\
\text { [5] Carrageenan-induced paw edema in } \\
\text { BALB/c mice; } \\
\text { [6] Ozone inhalation-induced pneumonia in } \\
\text { mice; }\end{array}$ & $\begin{array}{l}\text { [1] Radical reduction of ABTS, DPPH and FRAP; } \\
\text { [2] Reduction of the expression of nuclear transcription } \\
\text { factor Kappa-B, IL-6 and TNF- } \alpha \text {; } \\
\text { [3] Antiproliferative for eosinophils in BAL, reduction of IL-4 } \\
\text { and IL-5; } \\
\text { [4] Reduction of IL-1 } \alpha \text {, IL-1B, IL-17 and TNF- } \alpha \text {; } \\
\text { [5] Decreased synthesis of prostaglandins (similar to } \\
\text { indomethacin); } \\
\text { [6] Decreased protein and polymorphonuclear population in } \\
\text { BAL and epithelial tissue; }\end{array}$ & $\begin{array}{l}\text { [1] AZEVEDO BC, 2019; } \\
\text { [2] AZEVEDO BC, et al., 2018; } \\
\text { [3] AZEVEDO BC, et al., 2018; } \\
\text { [4] ROJAS-DURAN R, et al., 2012; } \\
\text { [5] AGUILAR JL, et al., 2002; } \\
\text { [6] CISNEROS FJ, et al., 2005; }\end{array}$ \\
\hline $\begin{array}{c}\text { Schinus } \\
\text { terebinthifolius } \\
\text { Raddi }\end{array}$ & $\begin{array}{l}\text { [3] In vitro and fungi culture } \\
\text { (Saccharomyces cerevisiae); } \\
\text { [4] In vitro; } \\
\text { [5] Histamine-induced paw edema in rats; }\end{array}$ & $\begin{array}{l}\text { [1] Local reduction / inhibition of chemokine CXCL-1/KC, } \\
\text { and cytokines IL-1 } \alpha \text {, TNF- } \alpha \text { and IL-6; } \\
\text { [2] Elimination of DPPH radicals, inhibition of hemolysis and } \\
\text { lipid peroxidation in human erythrocytes and increased } \\
\text { activity of the antioxidant enzymes catalase and superoxide } \\
\text { dismutase; } \\
\text { [3] Reduction of lipid peroxidation (cell damage) by } \mathrm{H}_{2} \mathrm{O}_{2} \text { in } \\
\text { S. cerevisiae cells and elimination of DPPH and ORAC } \\
\text { radicals; } \\
\text { [4] Specific inhibition of phospholipase A2; } \\
\text { [5] Antihistamine and anti-edema activity; }\end{array}$ & $\begin{array}{l}\text { [3] DE OLIVEIRA VS, et al., 2020; } \\
\text { [4] JAIM MK, et al., 1995; } \\
\text { [5] NUNES-NETO PA, et al., } 2017\end{array}$ \\
\hline Mentha piperita & $\begin{array}{l}\text { [1] Macrophage culture and model of ear } \\
\text { edema induced by croton oil in mice; } \\
\text { [2] In vitro and culture of macrophages; } \\
\text { [3] Ear edema induced by loadenin and } \\
\text { skin wounds in mice; }\end{array}$ & $\begin{array}{l}\text { [1] Inhibition of NO production, prostaglandins E2 and } \\
\text { antiedema; } \\
\text { [2] Reduction of DPPH, hydroxyl and superoxide anion } \\
\text { radicals; Reduction of NO, TNF- } \alpha \text {, IL-6 and Prostaglandin } \\
\text { E2 (PGE2) production; } \\
\text { [3] Reduction of skin inflammation, anti-edema response, } \\
\text { reduction of pain; }\end{array}$ & [2]LI YX, et al., 2017; \\
\hline
\end{tabular}

Source: Dantas KLS, et al., 2020 .

\section{ANTI-INFLAMMATORY MECHANISM}

2] Reduction of the expression of nuclear transcriptio factor Kappa-B, IL-6 and TNF- $\alpha$; and IL-5;

4] Reduction of IL-1 $\alpha$, IL-1ß, IL-17 and TNF- $\alpha$;

] Decreased synthesis of prostaglandins (similar to (Dethacin)

BAL and epithelial tissue;

[1] Local reduction / inhir

lipid peroxidation in human erythrocytes and increased

activity of the antioxidant enzymes catalase and superoxide utase;

$S$. cerevisiae cells and elimination of DPPH and ORAC

radicals;

11] Inhibition of NO production, prostaglandins E2 and

E2 (PGE2) production;

reduction of pain

\section{REFERENCES}

[3] AZEVEDO BC, et al., 2018;

[4] ROJAS-DURAN R, et al., 2012;

[5] AGUILAR JL, et al., 2002

CISNEROS FJ, et al., 2005;

[2] DA ROCHA PS, et al., 2018;

[5] NUNES-NETO PA, et al., 2017

[1] SUN Z, et al, 2014

3] KEHILI S, et al., 2020;

REAS/EJCH | Vol.13(1) | e5663 | DOI: https://doi.org/10.25248/reas.e5663.2021 Página 8 de 9 


\section{FINAL CONSIDERATIONS}

Medicinal plants have benefited and continue to bring benefits to humanity. The literature reports a high number of plants with proven anti-inflammatory potential, a fact that enhances the development of new herbal medicines. The three plants covered in this article (Uncaria tomentosa, Schinus terebinthifolius Raddi and Mentha piperita) had their anti-inflammatory effects related to the inhibition of important inflammatory pathways, mainly by reducing the production of inflammatory mediators produced by leukocytes (cytokines and chemokines) the activity of important enzymes to trigger the cascade of arachidonic acid and antioxidant activity, contributing to the removal of reactive oxygen and nitrogen species.

\section{REFERENCES}

1. AGUILAR JL, et al. Anti-inflammatory activity of two different extracts of Uncaria tomentosa (Rubiaceae). Journal of Ethnopharmacology, 2002; 81(2): 271-276.

2. ANTI SMAl, et al. Anti-inflamatórios hormonais: glicocorticóides. Einstein, 2008; 6(1): 159-165.

3. AZEVEDO BC, et al. Aqueous extracts from Uncaria tomentosa (Willd. ex Schult.) DC. reduce bronchial hyperresponsiveness and inflammation in a murine model of asthma. Journal of ethnopharmacology, 2018; 218: 76-89.

4. BALBINO CA. Anti-inflamatórios: uma compreensão total. Pharmacia Brasileira, 2011; 18: 30-44.

5. AZEVEDO BC, et al. Antioxidant activity of an aqueous leaf extract from Uncaria tomentosa and its major alkaloids mitraphylline and isomitraphylline in Caenorhabditis elegans. Molecules, 2019; 24(18): 3299.

6. CHEN L, et al. Inflammatory responses and inflammation-associated diseases in organs. Oncotarget, $2018 ; 9(6): 7204$.

7. CISNEROS FJ, et al. An Uncaria tomentosa (cat's claw) extract protects mice against ozone-induced lung inflammation. Journal of ethnopharmacology, 2005; 96(3): 355-364.

8. MONTEIRO DCS, BRANDELLI CLC. Farmacobotânica: Aspectos Teóricos e Aplicação. Artmed Editora, 2017.

9. DA ROCHA PS, et al. Antioxidant and protective effects of schinus terebinthifolius raddi against doxorubicin-induced toxicity. Applied biochemistry and biotechnology, 2018; 184(3): 869-884.

10. DE OLIVEIRA VS, et al. Aroeira fruit (Schinus terebinthifolius Raddi) as a natural antioxidant: Chemical constituents, bioactive compounds and in vitro and in vivo antioxidant capacity. Food chemistry, 2020; 315: 126274.

11. FONSECA FIC, et al. Biodiversidade: educação, saúde e conservação. 2019.

12. FREITAS PR, et al. Abordagens terapêuticas nas doenças inflamatórias: uma revisão. 2019.

13. HERRO E, JACOB SE. Mentha piperita (peppermint). Dermatitis, 2010; 21(6): 327-329.

14. HONÓRIO ICG, et al. Genetic and chemical diversity of Uncaria tomentosa (Willd. ex. Schult.) DC. in the Brazilian Amazon. PloS one, 2017; 12(5): 0177103.

15. JAIN MK, et al. Specific competitive inhibitor of secreted phospholipase A2 from berries of Schinus terebinthifolius. Phytochemistry, 1995; 39(3): 537-547.

16. KAISER S, et al. Chemical differentiation between Uncaria tomentosa and Uncaria guianensis by LC-PDA, FT-IR and UV methods coupled to multivariate analysis: A reliable tool for adulteration recognition. Microchemical Journal, 2020; 152: 104346.

17. KASSUYA CAL. Aspectos gerais da inflamação e da dor. Coleção Cadernos Acadêmicos, 2013.

18. KEHILI S, et al. Peppermint (Mentha piperita L.) essential oil as a potent anti-inflammatory, wound healing and antinociceptive drug. European Journal of Biological Research, 2020; 10(2): 132-149.

19. LI YX, et al. In vitro antiviral, anti-inflammatory, and antioxidant activities of the ethanol extract of Mentha piperita L. Food science and biotechnology, 2017; 26(6): 1675-1683.

20. LIGUORI I, et al. Estresse oxidativo, envelhecimento e doenças. Intervenções clínicas no envelhecimento, $2018 ; 13: 757$.

21. MELO WF, et al. Propriedades físico-químicas da hortelã (Mentha piperita L.) e seus benefícios à saúde. Informativo Técnico do Semiárido, 2018; 12(2): 08-13.

22. MITCHELL JA, KIRKBYNS NS. Eicosanoids, prostacyclin and cyclooxygenase in the cardiovascular system. British journal of pharmacology, 2019; 176(8): 1038-1050.

23. NUNES-NETO PA, et al. The Effect of Schinus terebinthifolius Raddi (Anacardiaceae) Bark Extract on Histamine-Induced Paw Edema and lleum Smooth Muscle Contraction. Evidence-Based Complementary and Alternative Medicine, $2017 ; 2017$.

24. ROJAS-DURAN R, et al. Anti-inflammatory activity of Mitraphylline isolated from Uncaria tomentosa bark. Journal of Ethnopharmacology, 2012; 143(3): 801-804.

25. ROSAS EC, et al. Anti-inflammatory Properties of Schinus terebinthifolius and Its Use in Arthritic Conditions. In: Bioactive Food as Dietary Interventions for Arthritis and Related Inflammatory Diseases. Academic Press, 2019; 489-505.

26. SINGH R, et al. Asma. Atividades antibacterianas e antioxidantes de Mentha piperita L. Arabian Journal of Chemistry, 2015; 8(3): 322-328.

27. SOUSA IJO, et al. A diversidade da flora brasileira no desenvolvimento de recursos de saúde. REVISTA UNINGÁ REVIEW, 2017; 31(1).

28. SUN Z, et al. Chemical composition and anti-inflammatory, cytotoxic and antioxidant activities of essential oil from leaves of Mentha piperita grown in China. PloS one, 2014; 9(12): e114767.

29. TALLIMA H, EL RR. Arachidonic acid: physiological roles and potential health benefits-a review. Journal of advanced research, 2018; 11: 33-41.

30. WONGRAKPANICH S, et al. Uma revisão abrangente do uso de drogas anti-inflamatórias não esteróides em idosos. Envelhecimento e doença, 2018; 9(1): 143. 